\title{
The Phenomenon of Violence Against Women and Girls in Albania
}

\author{
Valbona Muça \\ University of "AleksanderXhuvani” Elbasan, \\ Department of Social Sciences, Faculty of Education Sciences Elbasan, Albania
}

\section{Феноменът насилие срещу жените и момичетата в Албания}

Валбона Муча

Департамент по социални науки, Факултет по образователни науки, Университет

“AleksanderXhuvani”, Елбасан, Албания

\section{Author Notes}

ValbonaMuça (D) https://orcid.org/0000-0002-5959-1736

Valbona Muça is a Ph.D. at the Department of Social Sciences, Faculty of Education Sciences

The University of "AleksanderXhuvani”, Elbasan, Albania.

She has no known conflict of interest to disclose.

Correspondence concerning this article should be addressed to Valbona Muça, 3001, University of "AleksanderXhuvani", Rr. Ismail Zyma, 3001, Elbasan, Albania. Email: bonamuca@yahoo.it

\section{Бележки за автора}

Валбона Муча (D) https://orcid.org/0000-0002-5959-1736

Валбона Муча е доктор в Департамент по социални науки, Факултет по образователни науки, Университет “AleksanderXhuvani”, Елбасан, Албания.

Няма конфликт на интереси.

Кореспонденцията, свързана със статията може да бъде адресирана до Email: bonamuca@yahoo.it 


\begin{abstract}
This study aims to analyze and evaluate the social services provided to girls and women victims of domestic violence, based on the practices implemented in the non-public and public sector through this sector's representatives' representatives. The group of subjects included in the study consists of representatives of the Ministry of Social Welfare and Youth, local government, and non-profit social centers for girls and women - victims of violence and the center's beneficiaries. Qualitative ethnographic methods were used to conduct this study. One of the most important findings of this study was that the primary need of raped girls and women is to provide shelter to guarantee a safe place with their children. Also, the findings of this study show that non-public social services for girls and women-victims of domestic violence are limited and very deficient. The lack of some services and their lack of coordination does not meet the needs of the subjects. From 2013-2019, the cases of denouncing domestic violence have increased because the state and non-profit organizations have played an essential role in raising their awareness. A vital contribution of this study is the relevant recommendations to improve social services for this target group.
\end{abstract}

Keywords: domestic violence, beneficiaries, psycho-social centers, social services.

\title{
Резюме
}

Това проучване има за цел да анализира и оцени социалните услуги, предоставяни на момичета и жени, жертви на домашно насилие, въз основа на практиките, прилагани в непубличния и публичния сектор чрез представители на този сектор в Албания. Групата от субекти, включени в изследването, се състои от представители на Министерството на социалните грижи и младежта, местната власт и социалните центрове с нестопанска цел за момичета и жени - жертви на насилие и бенефициенти на центъра. За провеждането на това проучване бяха използвани качествени етнографски методи. Едно от най-важните открития на това проучване беше, че основната нужда на изнасилените момичета и жени е да им се предостави подслон, за да се гарантира, че са на сигурно място с децата си. Също така констатациите от това проучване показват, че непубличните социални услуги за момичета и жени, жертви на домашно насилие, са ограничени и много дефицитни. 
Липсата на някои услуги и липсата на координация, не отговарят на нуждите на заинтересованите. От 2013-2019 г случаите на осъждане за домашно насилие са се увеличили, тъй като държавата и организациите с нестопанска цел са изиграли съществена роля за повишаване за тяхната осведоменост. Съществен принос на това проучване са съответните препорьки за подобряване на социалните услуги за тази целева група.

Ключови думи: домашно насилие, бенефициенти, психо-социални центрове, социални услуги.

ARTICLE INFO:
Original Article
Received: $20,07.2020$
Revised: $25,07.2020$
Accepted: $31,07.2020$

Проблеми на постмодерността / Postmodernism Problems Vol. 10, No. 2, 2020, ISSN: 1314-3700, https://pmpjournal.org https://doi.org/10.46324/PMP2002219 


\section{The Phenomenon of Violence Against Women and Girls in Albania}

Albanian society is facing dynamic developments and profound changes in the structures of social life. The passage of the transition period and the emergence of new modernization phenomena have increased the specific gravity of our society's social problems. Social phenomena such as abandonment of children, the category of street children, expansion of the spectrum of people with disabilities, the presence of violence against women and children, loneliness of the elderly, increase of persons related to drugs, alcohol, and prostitution have made more necessary the need to reform the Social Protection System and improve the structure of Social Care Institutions (Barner\&Carney2011).

In these conditions, facing the growing social challenges requires improving the structure of social services, expanding the Map of Social Care Institutions, better adapting the structure of needs to the structure of services provided by the state, local government, and non-governmental organizations. The right to social protection is reflected in the Constitution of Albania (Haxhiymeri, 1996).

According to Walker (1999), domestic violence continues to be a much bigger problem in the search for world states. Social services for survivors of domestic violence were driven by the protection, support, and empowerment of the movements of the 1960 and 1970s when women became aware of their shared experiences of domestic violence and began creating safe houses for surviving victims who needed to be rescued. These safe houses became the first domestic violence (Walker, Lenore, 1999). Today, the centers remain the main entry points for services such as emergency and transit accommodation, support and therapy groups, resource access support, and legal support. According to the National Strategy for Social Protection in Albania (2015-2020), the Social Protection system aims to go:

a) towards the de-institutionalization of residential care services - construction and transformation of institutions towards models based on family and community;

b) towards transforming residential social care institutions into new alternative communitybased alternative models aimed at family support and institutionalization prevention.

At the local level, municipalities will be responsible for assessing, planning needs, and delivering services. (Strategjia kombetare per mbrojtjen sociale 2015-2020). The reason for undertaking this study is related to the importance it has for the target group of abused women, the need 
assessment, and the center's role in meeting these needs, the social services network that the center offers to women victims of domestic violence. Since 1995, many measures have been taken in Albania to improve the legal and institutional framework regarding this treatment. Albania has also ratified several international conventions aimed at preventing and combating gender-based violence and domestic violence. The entry into force of the Law number 5182 date 12.01.2007 on Domestic Violence began to establish appropriate and coordinated mechanisms for handling cases. This has played a crucial role in this regard, as the primarily responsible institution for implementing this law in coordination with other line ministries.

The services provided to the victim are short-term and long-term. Short-term services include immediate protection and security, health support, housing (including safe transport), and information and assistance in initiating immediate protection orders. Long-term support includes: referral to employment offices in support of employment or to obtain a professional recommendation; referral to the social services department for economic assistance; long-term housing, counseling, and legal aid in case the victim of violence want to start divorce proceedings or a complaint against the abuser; counseling and psychotherapy to recover from trauma, but also for reintegration, as well as help for children (i.e., transfer to another kindergarten or school, counseling/therapy, if necessary, etc.). An essential policy document, drafted in 2016-2020 (Strategjia kombetare e barazise gjinore dhe plani i veprimit 2016-2020) by the Ministry of Social Welfare and Youth, in cooperation with the United Nations United States (Agency for International Development, United Nations Development Program, and United States Agency for International Development ) is theNational Action Plan for the Engagement of Men and Boys as Partners of Women and Girls for Gender Equality and Prevention of GenderBased Violence and Domestic Violence for the period 2014 - 2019.

Our study focused on the centers that provide psycho-social services for raped women in Albania, more specifically:

- identify the assessment that the center makes of the needs of abused women;

- identify how much these institutions provide social service and how cases are referred to;

- describe the mechanisms and instruments used to meet these needs.

- analyze the reasons why these women are raped;

- how the number of victims has evolved from 2013-2019? 


\section{Purpose, objectives and research questions of the study}

The study aims to:

$\checkmark$ assess the social services provided to women victims of domestic violence, based on the practices carried out by the center through the perspectives of representatives and beneficiaries themselves.

$\checkmark$ assess the needs of women victims of domestic violence, their perception of the quality of existing services, and how well the center prepares them after the reintegration process in society.

Study objectives:

1. To identify and analyze the social services provided to women victims of domestic violence during the years 2013-2019.

2. To identify and analyze the needs of women victims of domestic violence, as beneficiaries of social service practices provided for domestic violence.

3. To analyze the state's role concerning social services for women - victims of domestic violence through various theoretical and practical approaches and national and international documents.

4. Explore domestic violence issues against women treated by the center and the services provided for their treatment.

Study research questions

To answer the objectives of the paper, the study raises some research questions and specifically:

1. What are the social services for women victims of domestic violence provided in Albania?

2. How are the services organized, what problems they address, and the basic principles and their main activities?

3. What are the needs of women victims of domestic violence? To what extent do service providers fully meet the needs of victims of violence?

4. What are key people's views and attitudes regarding the organization and contribution of social services for women victims of domestic violence provided by the center?

5. What are the difficulties the center service providers face in organizing and providing social services for women victims of domestic violence from 2013-2019? 


\section{Methodology}

\section{Research methods used}

Qualitative ethnographic research is the research method that best suited the research goal and objectives offered to abused women. The qualitative ethnographic method creates the right ground for research on the usefulness of services and specifically selected the central state institutions and some OJF(a non-profit organization) farmers. They provide social services for women raped in Albania.

Collecting systematic data and analysis are complementary activities in ethnographic work. A case study provides many descriptive, expected, and non-expected data. Similar data are combined, while different data process someone's opinion on the collected observations and convey ongoing analysis. Fieldwork is the 'work' or essential activity of an ethnographer, describes fieldwork as being immersed in the environment by observing, speaking, and spending time with people. An ethnographer uses the five senses to obtain complete data from participants and the environment. In this context, based on the study's purpose to assess abused women's needs and social services by centers and institutions for these women as victims of domestic violence and referring to the 49 participants in the study, were used:

$$
\begin{array}{ll}
\checkmark & \text { secondary data analysis; } \\
\checkmark & \text { semi-structured interviews. }
\end{array}
$$

Specifically, for this study were interviewed: 13 women raped by the group of the beneficiaries of the center, 8 members of the staff of the centers, 3 specialists of the Ministry of Social Welfare and Youth; 12 specialists of state institutions; 12 inspectors of police commissariats; 1 mental health specialist (psychiatrist).

\section{Study population and sample}

The group of subjects included in this study consists of 49 respondents:

- 13 women victims of domestic violence beneficiaries at the center

- 8 members of the center staff

- 3 specialists of the Ministry of Social Welfare and Youth;

- 12 specialists of state institutions

- 12 inspectors of police commissariats 
- 1 mental health specialist (psychiatrist).

\section{Measuring instruments}

\section{Semi-structured interviews}

With semi-structured interviews, the interviewer has an exact list of issues to include and questions to be answered by the participants. However, in semi-structured interviews, the interviewer is prepared and consistent with the purpose where the topics are considered and willing to allow the interviewee to develop ideas and speak more broadly about the researcher's issue. The answers are open, and the emphasis is on pointing out the interviewee's points of interest. Interviews are an attractive suggestion for project researchers. At first glance, they do not seem to include many technical things and point out that researchers can conduct a conversation. There are many superficial similarities between a conversation and an interview. Interviews are more than just a conversation. The interviews include a range of assumptions and understandings about the situation, which are not generally related to a random conversation. The superficial resemblance between an interview and a conversation can generate an illusion of simplicity. We all converse, and, likely, most of us do not have much difficulty doing this. So an interview should be straightforward. As long as we know who we are going to talk to and what we want to ask, the rest must be clear.

\section{Design and pilot research instruments}

The semi-structured interview was initially piloted with two raped women, who were beneficiaries of the Elbasan Women's Forum's daily center, beneficiaries who are not subjects in the study for conducting interviews. These interviews were not coded, and their data were not included in the analysis of other interview data. After piloting the interview, the guide was clarified with the interview questions conducted with the groups and consulted with qualitative research professionals.

\section{Results}

The purpose of the data analysis in this study is to assess how much services are provided to victims of domestic violence, women, as most affected by violence, meet their needs and how they are prepared in these centers for life in the stage of reintegration, as they exit the center. To obtain the necessary information from the interviews conducted with the study's groups, 
recording audio interviews by telephone and keeping notes immediately after the interview was used. At the end of each interview, a summary of all that has been said during its development has been made. Qualitative data analysis is the process of systematizing the order, structure, and interpretation of the data collected. Quantitative data can be represented through tables and statistics and ensure that, from a large amount of data, the researcher brings the reader accurate information about the techniques used to analyze the data.

On the other hand, the qualitative researcher's difficulty is to describe the data within the limits of those few pages, even when dealing with a complicated and confusing process of data analysis or with a large volume of grounded data in words and figures. Quality researchers are justified by the idea that they cannot flexibly present all that amount of data. They need to be selective in what they offer and clarify that they also need to be treated as editors to identify critical pieces of analysis and prioritize others.

\section{Women's experiences and perceptions of violence}

Violence is something that is not lived. Violence is the main cause or concern of raped girls and women before being directed to a center. Their experiences vary from case to case and depend on the socioeconomic status of the women and girls. Some of them show concern with strong emotions, such as exaltation, euphoria, confusion, etc. Their perception of the "new situation", that is, their departure from the environment of violence, is accompanied by a sense of "liberation" from the previous state in which they found themselves. Most of them are married and have children. The latter feel and experience more emotions due to the change in environment and lifestyle. From interviews conducted at the center with raped women and girls, they claim that they have faced various forms of violence. They report physical violence, psychological violence, emotional and sexual violence. Violence has often been passed on to children. Violent women and girls usually tend to leave a violent environment, and most of them prefer to return to their families of origin and relatives. But they do not always find this support. We also see this finding in the center's staff's staff, who report a lack of support from their family members. Here is how the social worker states: "The main concern is not only the violence against women but also the lack of support from their families, as a result of the existing mentality. When you are married and have chosen your husband, even though he rapes you, the reasons for the onset of violence are various, from which we can list: alcohol use, gambling 
addiction, the involvement of perpetrators in criminal acts, problems with the violation of the law, etc. The past of perpetrators, both family, social and educational, is mostly low. In rare cases, we can say that abusers have a secondary or higher education background have to accept it.

\section{Women's perceptions of center services}

Cases at the center are referred by the police, the court, or other referrals. Each case addressed to the center is provided with immediate service according to the beneficiaries' urgent needs. Their situation is then assessed to design together with the plan's beneficiaries to help them with the relevant objectives. Generally, the beneficiaries have an appreciative and respectful attitude towards the staff. They are ready to act according to what they are advised. Still, negative reactions are not excluded, for example, when it comes to treating children, because there are women who say "he is my child, I treat it as I want" what I want here, "but the staff does not tolerate any form of violence against children or women. It is not excluded that women do not get involved or do not fit in with the shelter staff and leave it.

Considering the interviews of women who have claimed to have used existing shelter services, we can say that there is a consensus about quality. Positive judgment is very much influenced by the public service that shelters offer, but women have reservations about other services that the state provides for them and require more support. In particular, they acknowledge the need for more services to cover all of their needs. Beneficiaries are demanding an increase in economic aid from the state and consider it necessary to have more reception and psycho-social support services. Survivors of the violence say they have readily accepted shelter services as the only way out to cope with the situation they have gone through. The support they find there prepares them for integration into society.

\section{Staff perceptions about the services provided as well as the difficulties they face}

Staff difficulties during working with women appear when staff advises them on how to treat or parent them with children. For staff, this is the hardest part for women to accept. One of the concerns and anxieties that accompany women is mainly facing the world after leaving the center, their physical security, economic security, etc. In general, they always agree with the center's approaches, but there are also those women who have clear ideas of what they are looking for, regardless of what you offer them. The social worker and the center's psychologist 
claim that they divide them into two groups during their work with the center's beneficiaries regarding their perception about staying in the shelter. Beneficiaries, who are aware of the reason for staying in the shelter and have clear and well-defined objectives, form one group. The other group - positions women who are unclear about the reason for staying in the center, what they want, and what they benefit from services at the center. Family past, educational level, socioeconomic status, personality problems, violence cases, and perpetrators' typologies vary from one case to another. The services offered are for all beneficiaries without social class differences or status, and the beneficiaries are not selected, and there is no differentiation between them by the staff.

Some of the services are:

a) life insurance; b) meeting basic needs; c) the assistance provided by the staff for the adjustment process, both of the mother and the child; d) rehabilitation programs; e) reintegration programs, such as finding a job, i.e., coming to live independently; f) medical services; j) psycho-social counseling; g) continuous monitoring, even after leaving the center; $h$ ) employment opportunities; 1) vocational training; m) finding a haven.

\section{Perception of representatives of the Ministry for dealing with cases of domestic violence}

Interviews were conducted with specialists in the gender equality sector at the MOSWY(Ministry of Social Welfare and Youth). They work on drafting gender equality policies against gender-based violence and domestic violence, such as drafting and legal improvements, support for working structures, programs for capacity building for domestic violence, awareness, etc. The data obtained from interviews with Gender-Based Violence and Domestic Violence Specialists at the MOSWY indicate a lack of functioning of the National Referral Mechanism in organizing social services for violent girls and women across the country. This can be seen in the absence of coordination, non-management and the non-rapid and proper resolution of violence cases, and the lack of coordination between the interdisciplinary technical group actors. In most cases, there is no participation of all actors. One of the specialists claims that: the experience so far, little work has been done to strengthen inter-institutional cooperation in providing quality multidisciplinary services for survivors of domestic violence. There needs to be more commitment from all the actor's social, economic, social policies, local government, and individuals providing services for this target group. 
According to the MOSWY employees, the municipalities have had the government and nongovernmental organizations' support through pilot projects. National referral mechanisms have functioned better than cities that have not installed this mechanism or in the country's remote areas. There is a significant lack of social services at the local level in these municipalities, such as the lack of emergency centers, the lack of financial means to support victims of violence or witnesses to domestic violence. One finding of this study is that the National Mechanism of Referral of Domestic Violence Cases is active in some municipalities. Still, its role is more preventive than acting. According to the interviewees, this shortcoming comes from the passivity and lack of involvement of many actors. Strengthening local government with functioning instruments, specialized human services, and domestic violence capacities guarantees security and provides support for raped girls and women.

\section{Discussions}

The study sheds light on the social services offered by the non-public and public sector in Albania to the surviving daughters and wives of Domestic Violence and its importance. The findings report that non-public social services for domestic violence victims exist, but are insufficient and well-coordinated. At the same time, the social services provided by the state to survivors of violence are still developing. The study results showed that the non-public sector's social services are insufficient to meet domestic violence survivors' needs.

This study found that providing social services to victims and survivors of domestic violence in Albania is still ongoing. However, specific standard procedures and common practices are practiced for domestic abuse cases at present. Disputes over the effectiveness of services usually occur that abused girls and women are not well informed about these resources' working mechanisms. On the other hand, the various organizations operating for domestic violence are also associated with their limitations. This is a standard practice to deal with violence with some agencies, affecting service delivery efficiency. Thus, based on the interviewed women's answers, the difficulties and obstacles in the procedures faced by raped women during the partner's detection of violence should be minimized to expand Albania's future services. What is interesting in this research's findings is the opportunity created for abused women to express their feelings and share their experiences with others to understand their needs better? It was found that almost all respondents were satisfied to submit a series of suggestions to improve the 
service situation to aid all girls and women victims of domestic violence. Another interesting finding of this study is the domestic violence phenomenon that is inherited. Interviews with abused women showed that they had experienced violence in the family of origin, a model inherited from the traditional and patriarchal mentality deeply rooted in Albanian culture. Most beneficiaries claim that they did not support the family of origin in trauma situations, for this inherited mentality. This factor forces raped girls and women to seek help from the state, receive services, and meet their needs. The findings of the study claim a good record of beneficiaries with the center's staff. Still, the difficulties faced by the center's employees in dealing with beneficiaries become an obstacle to ensuring the quality and efficiency of the services provided at the center.

\section{Conclusions}

Regarding the assessment of social services provided by the non-state and state sector for girls and women victims of Domestic Violence, the study provided a picture of the practices of these services, according to the views and attitudes of representatives of the Ministry of Social Welfare and Youth, Violence Specialists with Gender and Domestic Violence Based on local government, police officers, center staff and some service beneficiaries provided by the center. After an extensive analysis of the situation of the non-state services offered by the Center for Girls and Women Victims of Domestic Violence, we conclude that girls and women victims of violence are still many, and very little is done to meet their needs. The non-public social services offered by the center for girls and women who survived the violence are numerous, but still developing. They are insufficient and uncoordinated. The service and care given to survivors of domestic violence should not only help to overcome trauma and protect them, but also meet their needs and prepare them for a new life to integrate into society. Albania's decentralization of social services brings obligations to the local government to design clear policies focusing on domestic violence victims. So far, in terms of decentralizing social care services, through the possibility of introducing alternative services (daycare centers, emergency centers, rehabilitation centers, and residential centers), more efforts have been made by the private sector that is often not coordinated by the state. Local government units and, in particular, local coordinators have been legally charged as part of the National Violence Referral Mechanism to report cases of violence and coordinate their actions with other actors to assist victims, to assess their condition, 
and prepare an aid plan. The law recognizes the right to establish victim rehabilitation centers and crisis centers to the local government. The data show a massive shortage of services in this sector.

The national and international legal framework analysis enabled a clear picture of domestic violence victims and their right to social services. Dealing with different theoretical approaches and using them to discuss findings was necessary, given the fact that the development of social services for domestic violence is a process with limited experience for our country. 


\section{References}

Barner, J. \& Carney, M.(2011). Interventions for Intimate Partner Violence: A Historical Review. Journal of Family Violence, 26(3), 235-254. 10.1007/s10896-011-9359-3

Bozo, A. (2018). Draft Report on the evaluation of the Referral Mechanism's functioning against Domestic Violence at the local level. AWENWomen Empowerment Network. https://awenetwork.org/wp-content/uploads/2020/02/RAPORT-UMM_UM-AWENShqip.pdf

Browne, A. (1993).Violence against women by male partners: Prevalence, outcomes, and policy implications. American Psychologist, 48(10), 1077-1087. https://doi.org/10.1037/0003066X.48.10.1077

Haxhiymeri, E. (1996). Dhuna në familje në Shqipëri [Domestic violence in albania]. [Ph.D. Thesis, University of Tirana].

Law No. 9355. On social assistance and services (2005). The Assembly of Albania. http://observator.org.al/wpcontent/uploads/2015/11/Ligji_9355_per_ndihmen_ekon.dhe _sherbimet_sociale.pdf

Law No. 9669. On measures against domestic violence (2006). Assembly of Albania http://www.pp.gov.al/web/ligj_masat_kunder_dhunes_ne_familje_30.pdf

Law No. 9970 On gender equality in society (2008, July 24). Assembly of Albania. https://www.mod.gov.al/images/PDF/barazia_gjinore_shoqeri.pdf

Haxhiymeri, E., Kulluri,E., Hazizaj, A. (2005).Child abuse in the family. Children's Human Rights Centre of Albania. https://www.crca.al/en

National Strategy for Social Protection 2015-2020. https://shendetesia.gov.al/wpcontent/uploads/2018/06/Strategjia_Kombetare_per_Mbroj tjen_Sociale_2015-2020.pdf

Strategjia kombëtare për barazinë gjinore dhe plani i veprimit 2016-2020. Mireqenies sociale rinise the sporteve [National Strategy for Gender Equality and Action Plan 2016-2020. Ministry of Social Welfare, Youth and Sports]. https://www.un.org.al/sites/default/files/SKGJB-AL-web.pdf

Walker, A., Lenore, E. (1999). The Battered Woman Syndrome. Springer Publishing Company 
Walker, L. (1994). Abused Women and Survivor Therapy: A Practical Guide for the Psychotherapist. Washington. American Psychological Association. 